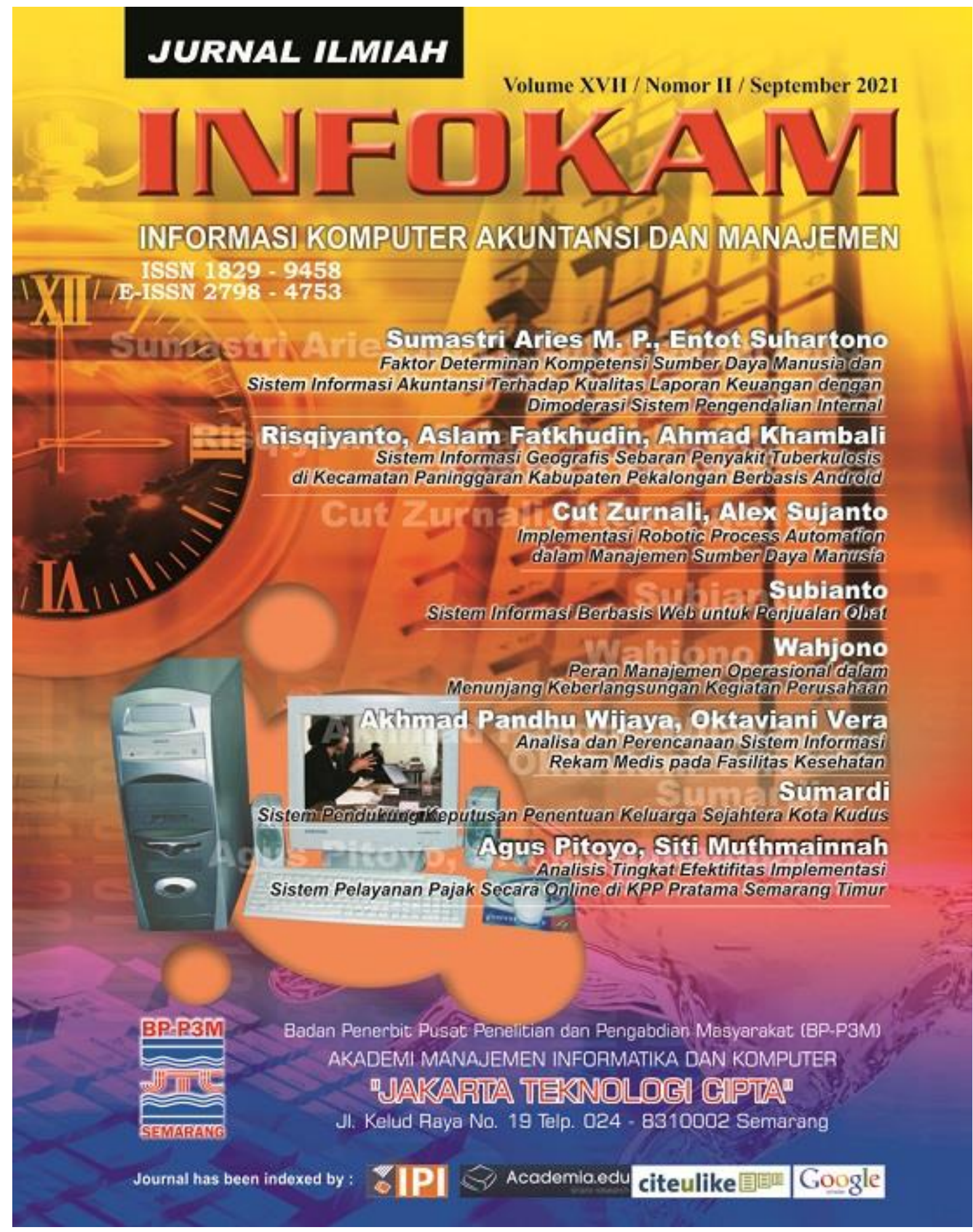


INFORMASI KOMPUTER AKUNTANSI DAN MANAJEMEN

ISSN 1829 - 9458

E-ISSN 2798 - 4753

SK DIREKTUR AMIK "JTC" SEMARANG

NO. 6305/AMIKJTC/D/IX/2020

Penasehat : Dr. Alex Sujanto, SE, S.Pd, MM. (Direktur)

Pengarah : Kristiawan Nugroho, M.Kom (Pudir I)

Muhamad Danuri, M.Kom (Pudir III)

Penanggung Jawab : Sumardi, S.Kom, M.Kom (Ka Progdi KA)

Subianto, S.Kom, M.Kom (Ka.Progdi MI)

Ketua Dewan Redaksi

Wahjono, SE, M.Si (Ketua Editor)

Sekretaris Editor

Anton Sujarwo, M.Si

Bendahara

Agus Pitoyo, M.Si

Anggota Dewan Editor

Subianto, M.Kom

Sumardi, M.Kom

Dr. Heru Sulistyo, SE, MSI ( STIE Dharmaputra Semarang)

Agus Prasetyo Utomo, MM., M.Kom (Univ. Stikubank Semarang)

Ira Setiawati, SE, M.Si (Univ. PGRI Semarang)

Eko Riyanto, S.Pd, M.Kom (STMIK Himsya Semarang)

Editor Teknis Dan Pelaksana

Sugeng Murdowo, S.T, S.Kom, M.Kom

Dr. Alex Sujanto, SE, S.Pd, MM

Mitra Bestari Peer Reviewer

Komputer

Daniel Alfa Puryanto, M.Kom (STMIK AKI Pati)

Aslam Fathkudin, M.Kom (Univ. Muh. Pekajangan Pekalongan)

Entot Suhartono, M.Kom (Univ. Dian Nuswantoro)

Fata Nida'ul Khasanah, M.Eng (Univ. Bhayangkara Jakarta Raya)

Noor Azizah, S.Kom, M.Kom (Univ. Islam Nahdatul Ulama Jepara)

\section{Akuntansi}

Dr. Heru Sulistiyo, M.Si, Akt (STIE Dharmaputra Semarang)

Arini Novandalina, M.Si (STIE Semarang)

Manajemen

Prof. Dr. Amron, SE. MM (Univ. Dian Nuswantoro Semarang)

Entot Suhartono, M. Kom (Univ. Dian Nuswantoro Semarang)

\section{Section Editor}

Subianto, S.Kom, M.Kom

Jurnal Ilmiah INFOKAM terbit minimal setiap 6 bulan sekali $(2 \mathrm{X}$ dalam setahun, bulan Maret \& September ) oleh AMIK "JTC" Semarang dengan maksud sebagai media informasi tentang Komputer, Akuntansi dan Manajemen bagi Sivitas Akademika pada khususnya dan masyarakat pada umumnya.

Alamat Redaksi / Penerbit :

Badan Penerbit Pusat Penelitian dan Pengabdian Masyarakat (BP-P3M)

AKADEMI MANAJEMEN INFORMATIKA DAN KOMPUTER

"JAKARTA TEKNOLOGI CIPTA"

Jl. Kelud Raya No. 19 Telp. 024 - 8310002 Semarang www.amikjtc.com/jurnal, email : infokam.amikjtc@gmail.com 


\section{INFORMASI KOMPUTER AKUNTANSI DAN MANAJEMEN \\ ISSN 1829 - 9458 \\ E-ISSN 2798 - 4753}

\section{DAFTAR ISI}

Faktor Determinan Kompetensi Sumber Daya Manusia dan Sistem Informasi Akuntansi Terhadap Kualitas Laporan Keuangan dengan Dimoderasi Sistem Pengendalian Internal

Sumastri Aries M. P., Entot Suhartono

Sistem Informasi Geografis Sebaran Penyakit Tuberkulosis di Kecamatan Paninggaran Kabupaten Pekalongan Berbasis Android

Risqiyanto, Aslam Fatkhudin, Ahmad Khambali

Implementasi Robotic Process Automation Dalam Manajemen Sumber Daya Manusia

Cut Zurnali, Alex Sujanto

Sistem Informasi Berbasis Web untuk Penjualan Obat

Subianto

Peran Manajemen Operasional dalam Menunjang Keberlangsungan Kegiatan Perusahaan

Wahjono

Analisa dan Perencanaan Sistem Informasi Rekam Medis pada Fasilitas Kesehatan

Akhmad Pandhu Wijaya, Oktaviani Vera

Sistem Pendukung Keputusan Penentuan Keluarga Sejahtera Kota Kudus Sumardi

Analisis Tingkat Efektifitas Implementasi Sistem Pelayanan Pajak Secara Online di KPP Pratama Semarang Timur Agus Pitoyo, Siti Muthmainnah 


\title{
Analisis Tingkat Efektifitas Implementasi Sistem Pelayanan Pajak Secara Online di KPP Pratama Semarang Timur
}

\author{
Agus Pitoyo, Siti Muthmainnah \\ Komputerisasi Akuntansi \\ AMIK Jakarta Teknologi Cipta Semarang
}

\begin{abstract}
Abstrak
Kepatuhan wajib pajak merupakan suatu keadaan di mana Wajib Pajak memenuhi semua kewajiban perpajakan dan melaksanakan hak perpajakanya. Masih rendahnya tingkat atau masih banyak wajib pajak yang kurang pengetahuan tentang sistem informasi E-Registration, E-SPT dan E-Filling, sehingga perlu ditingkatkan sosialisasi mengenai sistem informasi tersebut, yang akan meningkatkan kesadaran Wajib Pajak untuk mematuhi kewajiban perpajakan. Penelitian ini bertujuan untuk mengukur dan mengetahui tingkat efektivitas Implementasi Sistem Informasi EFilling, E-Registration, dan E-SPT terhadap tingkat kepatuhan Wajib Pajak Orang Pribadi. Teori yang digunakan dalam penelitian ini adalah Teori Technology Accepance Model (TAM), Teori Atribusi dan Teori Theory of Planned Behaviour. Penelitian ini menggunakan Variabel independen yaitu Kepatuhan Wajib Pajak dan variabel dependen yaitu Sistem E-Filling (X1), Sistem ERegistration (X2) dan Sistem E-SPT (X3). Analisis Data dalam penelitian ini adalah Analisis Kuantittatif. Tools Analisis Data dengan menggunakan Uji Reliabilitas, Uji Validitas, Analisis Regresi Berganda, Uji Asumsi Klasik, Uji Normalitas, Uji Multikolonieritas, Uji Heteroskedasitas dan Uji Hipotesa.

Keyword : Wajib Pajak, E-Filling, E-Spt, E-Registration
\end{abstract}

\begin{abstract}
Taxpayer compliance is a condition in which the taxpayer fulfills all tax obligations and exercises his tax rights. The level of taxpayers is still low or there are still many taxpayers who lack knowledge about E-Registration, E-SPT and E-Filling information systems, so it is necessary to increase the socialization of these information systems, which will increase taxpayer awareness to comply with tax obligations. This study aims to measure and determine the level of effectiveness of the Implementation of EFilling Information Systems, E-Registration, and E-SPT on the level of compliance of individual taxpayers. The theory used in this study is the Technology Accepance Model (TAM) Theory Attribution and Theory of Planned Behavior. This study uses the independent variable, namely Taxpayer Compliance and the dependent variable, namely the E-Filling System (X1), E-Registration System (X2) and E-SPT System (X3). Data analysis in this study is quantitative analysis. Data Analysis Tools using Reliability Test, Validity Test, Multiple Regression Analysis, Classical Assumption Test, Normality Test, Multicollinearity Test, Heteroscedasticity Test and Hypothesis Testing.
\end{abstract}

Keyword: Taxpayer, E-Filling, E-Spt, E-Registration

\section{Pendahuluan}

Berbagai cara diterapkan oleh pemerintah untuk menarik iuran pajak pada masyarakat, salah satunya dengan mewajibkan setiap perseorangan atau badan memiliki NPWP (Nomor Pokok Wajib Pajak). Wajib pajak merupakan orang pribadi atau badan, meliputi pembayar pajak, pemotong pajak, dan pemungut pajak, yang mempunyai hak dan kewajiban perpajakan sesuai dengan ketentuan peraturan perundang-undangan perpajakan (Resmi, 2013).Upaya Direktorat Jendral Pajak untuk mempermudah Wajib Pajak mendaftarkan NPWP melalui sistem pendaftaran online ternyata belum banyak diminat.

Tingkat kepatuhan wajib pajak dipengaruhi oleh bagaimana administrasi perpajakan dilakukan.Cara meningkatkan kepatuhan Wajib Pajak, Direktorat Jendral Pajak berupaya mengoptimalkan peningkatan kualitas pelayanan dengan dikembangkannya pelaporan pajak terutang dengan menggunakan Surat Pemberitahuan Elektronik (e-SPT).Menyikapi perkembangan tersebut, Direktorat Jenderal Pajak mengeluarkan keputusan Direktur Jenderal 
Pajak Nomor 6/PJ/2009 Tentang Tata Cara Penyampaian Surat Pemberitahuan dalam bentuk Elektronik. e- SPT merupakan penyampaian SPT dalam bentuk digital ke KPP secara elektronik atau dengan menggunakan media komputer (Rahayu, 2013).

Tujuan penelitian ini adalah

a. Untuk mengetahui pengaruh penerapan sistem e-Registration terhadap Kepatuhan Wajib Pajak Orang Pribadi pada KPP Pratama Semarang Timur.

b. Untuk mengetahui pengaruh penerapan sistem e-SPT terhadapKepatuhan Wajib Pajak Orang Pribadi pada KPP Pratama Semarang Timur.

c. Untuk mengetahui pengaruh penerapan sistem e-Filling terhadap Kepatuhan Wajib Pajak Orang Pribadi pada KPP Pratama Semarang Timur.

\section{Tinjauan Pustaka}

\section{a. Technology Accepance Model (TAM)}

Technology Accepance Model (TAM) merupakan suatu model penerimaan sistem teknologi informasi yang akan digunakan oleh pemakai. Model TAM dikembangkan oleh Davis et al (1989). TAM menambahkan dua konstruk utama ke dalam model TRA. Dua konstruk utama ini adalah kegunaan persepsian (perceived usefulness) dan Kemudahan penggunaan persepsian (perceived ease of use). TAM beragumentasi bahwa penerimaan individual terhadap sistem teknologi informasi ditentukkan oleh 2 konstruk tersebut.

Pemakai teknologi pada penelitian adalah WP OP, Sedangkan penerapan sistem teknologinya yakni, e-SPT dan e-Filling. Technology Acceptance Mode/ ini diharapkan dapat menjelaskan bagaimana penggunaan, e-SPT dan e-Filling mempengaruhi kepatuhan pelaporan WP OP. Peneliti menggunakan teory TAM karena peneliti ingin mengetahui seberapa besar kepatuhan pelaporan WP OP minat terhadap penggunaan teknologi e-SPT dan e-Filling terhadap kepatuhan wajib pajak, diharapkan dengan adanya kemudahan teknologi WP OP memanfaatkan teknologi ini dengan sungguh-sungguh (Jogiyanto, 2008)

\section{b. Teori Atribusi}

Teori Atribusi menjelaskan mengenai proses bagaimana kita menentukan penyebab dan motif tentang perilaku seseorang. Teori ini mengacu tentang bagaimana seseorang menjelaskan penyebab perilaku orang lain atau dirinya sendiri yang akan ditentukan apakah dari internal misalnya sifat, karakter, sikap, dll ataupun eksternal misalnya tekanan situasi atau keadaan tertentu yang akan memberikan pengaruh terhadap perilaku individu. Teori atribusi relevan untuk menjelaskan faktor-faktor yang dapat mempengaruhi kepatuhan wajib pajak yang digunakan dalam model penelitian ini. Kepatuhan wajib pajak dapat dikaitkan dengan sikap wajib pajak dalam membuat penilaian terhadap pajak itu sendiri. Persepsi seseorang untuk membuat penilaian mengenai orang lain sangat dipengaruhi oleh faktor internal maupun eksternal. Dalam penelitian ini, peneliti menggunakan teori atribusi karena peneliti akan melakukan studi empiris untuk mengetahui faktor-faktor yang mempengaruhi kepatuhan wajib pajak. Pada dasarnya karakteristik personal seorang wajib pajak merupakan salah satu penentu terhadap kenaikan tingkat membayar pajak karena merupakan suatu faktor internal yang mendorong seseorang untuk melakukan suatu aktivitas.

\section{c. Theory of Planned Behaviour}

Theory of planned behavior (TPB) menyatakan bahwa teori perilaku yang direncanakan menyediakan kerangka kerja konseptual yang berguna untuk berurusan dengan kompleksitas perilaku sosial manusia. Teori ini menggabungkan beberapa pusat konsep dalam ilmu-ilmu sosial dan perlaku dan itu mendefinisikan konsep- konsep ini dengan cara yang memungkinkan prediksi dan pemahaman tentang perilaku tertentu dalam konteks tertentu sikap terhadap perilaku tinggi (Ajzen, 1991). Kajian pada bidang psikologi yang dapat menjelaskan faktor yang mempengaruhi kepatuhan perpajakan adalah melalui Theory of Planned Behaviour. Berdasarkan model TPB, ketentuan perpajakan dapat dipatuhi oleh seorang individu apabila didalam diri sendiri individu tersebut memiliki intention (niat). Fase dimana seseorang akan memiliki niat untuk kemudian memasuki fase terakhir adalah fase dimana individu akan mulai berperilaku (behavior) (Mustikasari, 2007).

\section{d. Pajak}

Pajak adalah peralihan kekayaan dari pihak rakyat kepada kas Negara untuk membiayai pengeluaran rutin dan "surplus"-nya digunakan untuk public saving yang 
merupakan sumber utama untuk membiayai public investment (Resmi, 2013). Menurut S.I. Djajadiningrat (Resmi, 2013) menyatakan bahwa pajak sebagai suatu kewajiban menyerahkan sebagian dari kekayaan ke kas Negara yang disebabkan suatu keadaan, kejadian, dan perbuatan yang memberikan kedudukan tertentu, tetapi bukan sebagai hukuman, menurut peraturan yang ditetapkan pemerintah serta dapat dipaksakan, tetapi tidak ada jasa timbal balik dari Negara secara langsung, untuk memelihara kesejahteraan secara umum.

\section{e. E-Sistem ( Elektronik Sistem)}

Dalam era globalisasi pelayanan pajak yang diberikan juga mendukung modernisasi yaitu dalam bentuk pengembangan dan penerapan sistem informasi. Direktorat Jenderal Pajak menyediakan fasilitas-fasilitas pelayanan yang berbasis computer dan online, esistem digunakan untuk meningkatkan kualitas pelayanan pajak guna memberikan kemudahan kepada Wajib Pajak untuk melaksanakan administrasi perpajakanya, terdapat beberapa e-system yang dapat dimanfaatkan masyarakat atau wajib pajak yaitu $e$ Registration, e-SPT, dan e-Filling. Hal ini dilakukan untuk mewujudkan sistem adminstrasi perpajakan yang modern

\section{f. Aplikasi e-Sistem Administrasi Perpajakan}

Perkembangan teknologi pemrosesan data telah mengalami perkembangan yang luar biasa dengan ditemukannya komputer, yaitu pemrosesan data secara elektronik. Komputer sebagai alat pemrsesan data dan sebagai suatu sistem informasi dalam perusahaan, telah dilengkapi dengan teknologi informasi yang dalam perkembangan sering disebut sebagai sistem teknologi informasi. Berdasarkan keputusan Direktorat Jenderal Pajak No. KSP88/PJ/2004 tentang penyampaian surat pemberitahuan secara elektronik melalui perusahaan penyedia aplikasi yang ditunjuk oleh Direktorat Jenderal Pajak. ASP (Application Service Provider) adalah perusahaan penyedia jasa aplikasi yang ditunjuk oleh Direktorat Jenderal Pajak sebagai perusahaan yang dapat menyalurkan penyampaian Surat Pemberitahuan secara elektronik ke Direktorat Jenderal Pajak.

\section{g. e-Registration}

e-Registration merupakan sistem pendaftaran, perubahan data Wajib Pajak dan atau pengukuhan maupun pencabutan pengukuhan Pengusaha Kena Pajak melalui sistem yang terhubung langsung secara online dengan DJP ( Rahayu, 2013). Dasar pengembangan dari e-Registration ini adalah Surat Edaran Direktur Jenderal Pajak Nomor SE - 59/PJ/2007 Tentang Penyampaian Peraturan Direktur Jenderal Pajak Nomor PER-160/PJ./2007 Tentang Perubahan Atas Keputusan Direktur Jenderal Pajak Nomor KEP-161/PJ/2001 tentang Kegiatan Usaha, Tata Cara Pendaftaran dan Penghapusan Nomor Pokok Wajib Pajak, serta Pengukuhan dan Pencabutan Pengukuhan Pengusaha Kena Pajak.

h. e-SPT

Aplikasi e-SPT merupakan aplikasi yang diberikan secara gratis oleh Direktorat Jenderal Pajak. Aplikasi e-SPT dapat digunakan untuk merekam, memelihara dan merubah data digital serta mencetak SPT beserta lampirannya.

\section{i. e-Filling}

e-Filling merupakan cara penyampaian SPT melalui sistem online dan real time. Wajib Pajak dapat menyampaikan SPT secara elektronik melalui perusahaan penyedia jasa aplikasi (application service provider) yang telah ditunjuk DJP sebagai perusahaan yang dapat menyalurkan penyampaian SPT secara elektronik. Berdasarkan Keputusan Peraturan Direktur Jenderal Pajak Nomor 47/PJ/2008 tentang Tata Cara Penyampaian Surat Pemberitahuan dan Penyampaian Pemberitahuan Perpanjangan Surat Pemberitahuan Tahunan Secara Elektronik ( $e$ - Filling) melalui Perusahaan Penyedia Jasa Aplikasi (ASP) (Casavera, 2009),

\section{Keterkaitan Antar Variabel}

\section{a. Hubungan antara Penerapan Sistem e-Registration dengan Kepatuhan Wajib Pajak Orang Pribadi}

Hasil Penelitian yang dilakukan Putra, dkk (2015) menunjukkan bahwa variabel Penerapan sistem e-Registration secara signifikan berpengaruh terhadap kepatuhan Wajib Pajak. Variabel Sistem e-Registration mempunyai pengaruh yang paling kuat atau dominan dengan variable yang lainnya, maka Variable Sistem e- Registration mempunyai pengaruh yang dominan terhadap Kepatuhan Wajib Pajak. Sedangkan Penelitian yang dilakukan 
Syafariani, dkk (2015) menunjukkan bahwa Peranan kualitas sistem e-registration menunjukkan hasil bahwa ada peranan atau kontribusi antara variabel kualitas sistem $e$ registration secara simultan dan parsial secara signifikan terhadap kepuasan dan kepatuhan wajib pajak.

b. Hubungan antara Penerapan Sistem e-SPT dengan Kepatuhan Wajib Pajak Orang Pribadi

Hasil Penelitian Putra, dkk (2015) menunjukkan hasil bahwa Variabel Penerapan Sistem e-SPT secara signifikan berpengaruh terhadap kepatuhan Wajib Pajak. Sedangkan Penelitian yang dilakukan oleh Zuhdi, dkk (2015) menunjukkan bahwa hasil dari uji simultan dan uji parsial penerapan e-SPT berpengaruh signifikan terhadap kepatuhan wajib pajak. Pengujian ini memberikan bukti empiris bahwa penerapan sistem e-SPT memberikan kontribusi yang signifikan terhadap kepatuhan wajib pajak. Penelitian yang dilakukan oleh Indrayanto (2015) menunjukan bahwa Penerapan e-SPT memberikan pengaruh yang signifikan terhadap Kepatuhan Wajib Pajak .

c. Hubungan antara Penerapan Sistem e-Filling terhadap Kepatuhan Wajib Pajak Orang Pribadi.

Hasil Penelitian Putra, dkk (2015) menunjukkan hasil bahwa Penerapan Sistem e-Filling secara signifikan berpengaruh terhadap kepatuhan Wajib Pajak. Sedangkan Penelitian yang dilakukan Susmita, dkk (2016) menujukkan hasil bahwa Penerapan Sistem e-Filling secara signifikan berpengaruh positif maka analisis hipotesis tersebut dinyatakan signifikan dengan arah hubungan positif. Sedangkan Penelitian yang dilakukan oleh Nugroho, dkk (2014) menunjukkan hasil bahwa pengaruh e-Filling berpengaruh signifikan secara parsial maka variabel e-Filling berpengaruh signifikan untuk mendorong kepatuhan penyampaian SPT Tahunan PPh.

d. Kerangka Pemikiran

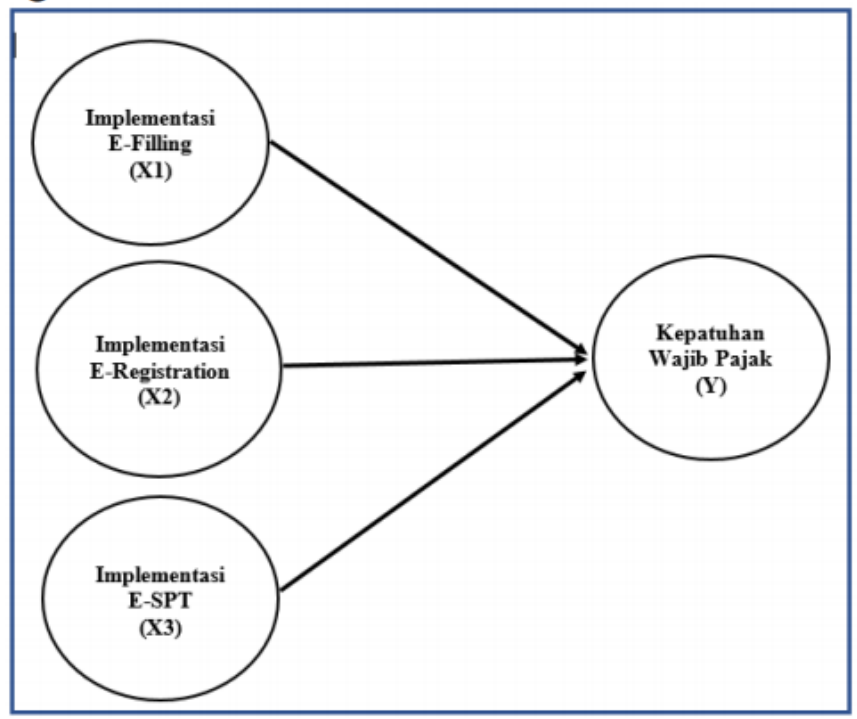

Gambar 1 ; Kerangka Pemikiran Penelitian

e. Hipotesis Penelitian

1) Pengaruh Penerapan Sistem e-Registration terhadap Kepatuhan Wajib Pajak Orang Pribadi

H1 : Penerapan Sistem e-Registration berpengaruh terhadap kepatuhan Wajib Pajak.

2) Pengaruh Penerapan Sistem e-SPT terhadap Kepatuhan Wajib Pajak Orang Pribadi.

H2 : Penerapan Sistem e-SPT berpengaruh terhadap kepatuhan Wajib Pajak.

3) Pengaruh Penerapan Sistem e-Filling terhadap Kepatuhan Wajib Pajak Orang Pribadi

H3 : Penerapan Sistem e-Filling berpengaruh terhadap kepatuhan Wajib Pajak. 


\section{Metode Penelitian}

a. Variabel Penerapan Sistem e-Registration

1) Dengan diterapkannya system e-Registration, wajib pajak dapat dengan mudah melakukan pendaftaran secara online.

2) Dengan diterapkannya sistem e-Registration, wajib pajak dapat melakukan perubahan data wajib pajak secara online.

3) Dengan diterapkannya sistem e-Registration, wajib pajak dapat melakukan pendaftaran wajib pajak baru jika ingin memperoleh nomor NPWP.

4) Dengan diterapkannya sistem e-Registration, wajib pajak tidak perlu lagimenunggu berkas pendaftaran dari Wajib Pajak untuk melakukan proses validasi NPWP.

5) Dengan diterapkannya sistem e-registration, wajib pajak dapat melihat informasi perubahan-perubahan secara administrative.

b. Variabel Penerapan Sistem e-SPT

1) Sistem e-SPT mudah dipelajari oleh pengguna (user friendly).

2) Sistem e-SPT dapat merekam data dengan cepat.

3) Dengan diterapkannya sistem e-SPT, wajib pajak dapat menyampaikan SPTsecara cepat dan aman, karena lampiran dalam bentuk media $\mathrm{CD} /$ flash disk.

4) Dalam sistem e-SPT Data perpajakan terorganisasi dengan baik.

5) Dalam sistem e-SPT dapat melakukan perhitungan secara cepat dan tepat karena menggunakan sistem komputer.

\section{c. Variabel Penerapan Sistem e-Filling}

1) Dengan diterapkanya sistem e-Filling wajib pajak dapat menyampaikan SPTdimanapun saya berada asal ada koneksi internet.

2) Dengan diterapkannya sistem e-Filling, memudahkan wajib pajak dalammelakukan perhitungan pajak.

3) Dengan diterapkanya sistem e-Filing ,wajib pajak tidak perlu mencetak semua formulir lampiran.

4) Dengan diterapkannya sistem e-Filling memudahkan wajib pajak dalampengisian SPT.

5) Sistem e-Filling ramah lingkungan karena meminimalisasi penggunaan kertas.

\section{Hasil dan Pembahasan}

a. Uji Kualitas Data

Penyebaran kuesioner pertama dilakukan dengan cara 30 kuesioner disebar di KPP Pratama Semarang Timur untuk mengetahui kualitas data suatu kuesioner. Proses selanjutnya adalah melakukan uji validitas dan uji realiabilitas terhadap masing-masing indikator dari variabel independen dan variabel dependen agar suatu kuesioner dapat dipakai didalam penelitian ini.

\section{b. Uji Validitas}

Untuk menguji valid dan tidaknya pernyataan yang akan diajukan dengan membandingkan nilai $r$ hitung dengan $r$ tabel.

1) Apabila $r$ hitung $>r$ tabel maka pernyataan valid.

2) Apabila $r$ hitung $<r$ tabel maka pernyataan tidak valid.

Tabel 1: Hasil Uji Validasi

\begin{tabular}{|l|c|c|c|c|}
\hline Variabel & No.item & r hitung & r table & Keterangan \\
\hline Sistem e- & 1 & 0,576 & 0,361 & Valid \\
Registration & 2 & 0,623 & & \\
& 3 & 0,584 & & \\
& 4 & 0,483 & & \\
& 5 & 0,584 & & \\
\hline Sistem e- & 1 & 0,448 & 0,361 & \\
SPT & 2 & 0,579 & & \\
& 3 & 0,524 & & \\
& 4 & 0,510 & & \\
\hline
\end{tabular}




\begin{tabular}{|l|l|l|l|l|}
\hline & 5 & 0,675 & & \\
\hline Sistem e- & 1 & 0,543 & 0,361 & Valid \\
Filling & 2 & 0,421 & & \\
& 3 & 0,569 & & \\
& 4 & 0,560 & & \\
\hline Kepatuhan & 5 & 0,421 & 0,361 & Valid \\
Wajib Pajak & 2 & 0,570 & & \\
& 3 & 0,620 & & \\
& 4 & 0,788 & & \\
& 5 & 0,599 & & \\
\hline
\end{tabular}

Sumber: Output SPSS 20

Berdasarkan hasil diatas dapat dijelaskan bahwa $r$ hitung $>r$ tabel $(0,361)$ dengan demikian dapat disimpulkan bahwa semua item dalam indikator variabel- variabel penelitian ini (Sistem e-Registration, e-SPT, e-Filling dan Kepatuhan Wajib Pajak) adalah valid.

\section{Hasil Analisis Data}

\section{a. Metode Analisis Regresi Berganda}

Model regresi berganda digunakan untuk menguji pengaruh dua atau lebih variabel independen terhadap variabel dependen dengan skala pengukuran interval atau rasio dalam suatu persamaan linier (Indriantoro, 2009).

\begin{tabular}{|c|c|c|c|c|c|c|c|c|}
\hline \multicolumn{9}{|c|}{ Coefficients $^{a}$} \\
\hline \multirow{2}{*}{\multicolumn{2}{|c|}{ Model }} & \multicolumn{2}{|c|}{$\begin{array}{l}\text { Unstandardized } \\
\text { Coefficients }\end{array}$} & \multirow{2}{*}{$\begin{array}{c}\text { Standardized } \\
\text { Coefficients }\end{array}$} & \multirow[t]{2}{*}{$\mathrm{T}$} & \multirow[t]{2}{*}{ Sig. } & \multicolumn{2}{|c|}{$\begin{array}{l}\text { Collinearity } \\
\text { Statistics }\end{array}$} \\
\hline & & B & Std. Error & & & & $\begin{array}{c}\text { Toleranc } \\
\mathrm{e}\end{array}$ & VIF \\
\hline \multirow{4}{*}{1} & (Constant) & 1,494 & ,523 & & 2,855 & ,005 & & \\
\hline & $\begin{array}{l}\text { Sistem e- } \\
\text { Registration }\end{array}$ & ,067 & , 124 & ,060 &, 539 & ,591 & 633 & 1,579 \\
\hline & Sistem e-SPT & , 138 & , 113 & , 136 & 1,223 & ,224 & ,645 & 1,551 \\
\hline & Sistem e-Filling &, 453 & ,142 & ,364 & 3,186 &, 002 & ,608 & 1,645 \\
\hline
\end{tabular}

a. Dependent Variable: Kepatuhan Wajib Pajak

Dari hasil output diatas pada kolom Beta dimasukkan kedalam persamaan :

Kepatuhan Wajib Pajak = 0,060 Sistem e-Registration + 0,136 Sistem e-SPT + 0,364 Sistem e-Filling

1) Koefisien regresi Sistem e-Registration $X 1=0,060$, bernilai positif, artinya semakin baik Sistem e-Registration akan meningkatkan Kepatuhan Wajib Pajak.

2) Koefisien regresi Sistem e-SPT X2 $=0,136$, bernilai positif, artinya semakin baik Sistem e-SPT akan meningkatkan Kepatuhan Wajib Pajak.

3) Koefisien regresi Sistem e-Filling $X 3=0,364$, bernilai positif, artinya semakin baik Sistem e-Filling akan meningkatkan Kepatuhan Wajib Pajak.

\section{b. Uji Normalitas}

Uji normalitas dilakukkan untuk mengetahui distribusi data atau normal tidaknya data pada variabel dependen dilakukan dengan menggunakan kolmogorov- smirnovtest (Ghozali, 2011). Hasil pengujian adalah sebagai berikut: 
One-Sample Kolmogorov-Smirnov Test

\begin{tabular}{|ll|r|}
\hline & & $\begin{array}{r}\text { Unstandardized } \\
\text { Residual }\end{array}$ \\
\hline $\mathrm{N}$ & Mean & 100 \\
Normal Parameters $\mathrm{a}, \mathrm{b}$ & Std. Deviation & $0 \mathrm{E}-7$ \\
& Absolute &, 36534392 \\
& Positive &, 070 \\
Most Extreme Differences & Negative &,- 042 \\
& &, 697 \\
Kolmogorov-Smirnov Z & &, 715 \\
Asymp. Sig. (2-tailed) & & \\
\hline
\end{tabular}

a. Test distribution is Normal.

b. Calculated from data.

\section{c. Uji Multikolinearitas}

Untuk mengetahui ada tidaknya multikolinearitas menurut perhitungan yang dilakukan dengan program SPSS dapat diketahui dengan berpedoman bahwa nilai VIF $<10$ dan Tolerance $>0,1$ (Ghozali, 2011). Hasil uji multikolinearitas dapat dilihat dari nilai tolerance dan VIF disajikan pada tabel berikut :

\begin{tabular}{|c|c|c|c|c|c|c|c|c|}
\hline \multicolumn{9}{|c|}{ Coefficients $^{a}$} \\
\hline \multirow{2}{*}{\multicolumn{2}{|c|}{ Model }} & \multicolumn{2}{|c|}{$\begin{array}{l}\text { Unstandardized } \\
\text { Coefficients }\end{array}$} & \multirow{2}{*}{$\begin{array}{c}\text { Standardize } \\
\text { d } \\
\text { Coefficients } \\
\text { Beta }\end{array}$} & \multirow[t]{2}{*}{$\mathrm{T}$} & \multirow[t]{2}{*}{ Sig. } & \multicolumn{2}{|c|}{$\begin{array}{l}\text { Collinearity } \\
\text { Statistics }\end{array}$} \\
\hline & & B & Std. Error & & & & $\begin{array}{c}\text { Toleranc } \\
\mathrm{e} \\
\end{array}$ & VIF \\
\hline \multirow{4}{*}{1} & (Constant) & 1,494 &, 523 & & 2,855 & ,005 & & \\
\hline & $\begin{array}{l}\text { Sistem e- } \\
\text { Registration }\end{array}$ & ,067 & ,124 & ,060 &, 539 &, 591 & 633 & 1,579 \\
\hline & Sistem e-SPT & , 138 & ,113 & ,136 & 1,223 & ,224 & ,645 & 1,551 \\
\hline & Sistem e-Filling &, 453 & , 142 &, 364 & 3,186 &, 002 & ,608 & 1,645 \\
\hline
\end{tabular}

a. Dependent Variable: Kepatuhan Wajib Pajak

Berdasarkan hasil tabel tersebut, dapat disimpulkan bahwa:

1) Sistem e-Registration (X1) mempunyai nilai Tolerance $0,633>0,1$ dan nilai VIF $1,579<$ 10 sehingga bebas dari Multikolonieritas.

2) Sistem e-SPT (X2) mempunyai nilai Tolerance 0,645 $>0,1$ dan nilai VIF 1,551<10 sehingga bebas dari Multikolonieritas.

3) Sistem e-Filling (X3) mempunyai nilai Tolerance 0,608 $>0,1$ dan nilai VIF 1,645 $<10$ sehingga bebas dari Multikolonieritas.

\section{d. Uji Signifikansi Simultan (Uji Statistik F)}

Uji $F$ bertujuan menunjukkan apakah dalam model regresi semua variabel independen atau bebas yang dimasukkan dalam model mempunyai pengaruh secara bersama-sama terhadap variabel dependen, yang diuji pada tingkat signifikan 0,05 (Ghozali, 2011). Hasil uji F dapat dilihat sebagai berikut:

\begin{tabular}{|c|c|c|c|c|c|c|}
\hline \multicolumn{7}{|c|}{ ANOVA } \\
\hline & & Sum of Squares & Df & Mean Square & $\mathrm{F}$ & Sig. \\
\hline \multirow{3}{*}{1} & Regression & 4,166 & 3 & \multirow{3}{*}{$\begin{array}{r}1,389 \\
, 138\end{array}$} & \multirow[t]{3}{*}{10,089} & \multirow[t]{3}{*}{, $000^{\mathrm{b}}$} \\
\hline & Residual & 13,214 & 96 & & & \\
\hline & Total & 17,380 & 99 & & & \\
\hline
\end{tabular}

a. Dependent Variable: Kepatuhan Wajib Pajak

b. Predictors: (Constant), Sistem e-Filling, Sistem e-SPT, Sistem e-Registration

Tabel tersebut dalam model ANOVA dapat diperoleh $\mathrm{F}$ hitung sebesar 10,089 dengan tingkat signifikan 0,000 . Oleh karena tingkat signifikan lebih kecil dari 0,05 maka variabel 
Sistem e-Registration, e-SPT dan e-Filling secara simultan atau bersama-sama berpengaruh signifikan terhadap variabel dependen yaitu Kepatuhan Wajib Pajak.

\section{e. Uji Statistik t}

Uji t bertujuan untuk menguji pengaruh satu variabel penjelas/independen secara individual dalam menerangkan variasi variabel dependen, dengan tingkat signifikansi 0,05 (Ghozali,2011). Hasil uji t dapat dilihat tabel berikut:

\begin{tabular}{|c|c|c|c|c|c|c|c|c|}
\hline \multicolumn{9}{|c|}{ Coefficients $^{a}$} \\
\hline \multirow{2}{*}{\multicolumn{2}{|c|}{ Model }} & \multicolumn{2}{|c|}{$\begin{array}{l}\text { Unstandardized } \\
\text { Coefficients }\end{array}$} & \multirow{2}{*}{$\begin{array}{c}\begin{array}{c}\text { Standardize } \\
\text { d }\end{array} \\
\text { Coefficients } \\
\text { Beta }\end{array}$} & \multirow[t]{2}{*}{$\mathrm{t}$} & \multirow[t]{2}{*}{ Sig. } & \multicolumn{2}{|c|}{$\begin{array}{l}\text { Collinearity } \\
\text { Statistics }\end{array}$} \\
\hline & & B & Std. Error & & & & $\begin{array}{c}\text { Toleranc } \\
\mathrm{e} \\
\end{array}$ & VIF \\
\hline \multirow{4}{*}{1} & (Constant) & 1,494 &, 523 & & 2,855 &, 005 & & \\
\hline & $\begin{array}{l}\text { Sistem e- } \\
\text { Registration }\end{array}$ & ,067 & 124 & ,060 & ,539 & ,591 & ,633 & 1,579 \\
\hline & Sistem e-SPT & , 138 & ,113 & , 136 & 1,223 & ,224 & ,645 & 1,551 \\
\hline & Sistem e-Filling &, 453 & , 142 & ,364 & 3,186 & ,002 & ,608 & 1,645 \\
\hline
\end{tabular}

a. Dependent Variable: Kepatuhan Wajib Pajak

Berdasarkan tabel tersebut hasil uji t dinyatakan bahwa:

1) Sistem e-Registration (X1) memiliki nilai sig 0,591 > 0,05 maka $\mathrm{H} 1$ tidak diterima. Hal ini menunjukkan bahwa variabel Sistem e-Registration tidak berpengaruh terhadap Kepatuhan Wajib Pajak.

2) Sistem e-SPT (X2) memiliki nilai sig 0,224 >0,05 maka $\mathrm{H} 2$ tidak diterima.

3) Sistem e-Filling (X3) memiliki nilai sig 0,002 < 0,05 maka H3 diterima. Hal ini menunjukkan bahwa variabel Sistem e-Filling berpengaruh terhadap Kepatuhan Wajib Pajak.

Hal ini menunjukkan bahwa variabel Sistem e-SPT tidak berpengaruh terhadap Kepatuhan Wajib Pajak.

\section{Pembahasan}

Penelitian ini merupakan penelitian yang menganalisis mengenai pengaruh penerapan sistem e-Registration, e-SPT dan e-Filling terhadap Kepatuhan Wajib Pajak.

a. Pengaruh Penerapan Sistem e-Registration terhadap Kepatuhan Wajib Pajak

Hasil penelitian menunjukkan bahwa Sistem e-Registration tidak berpengaruh terhadap kepatuhan wajib pajak, sedangkan hasil uji signifikan simultan sistem e-Registration berpengaruh signifikan terhadap kepatuhan wajib pajak. Berdasarkan data yang diperoleh dari jawaban responden pada kuesioner secara keseluruhan wajib pajak orang pribadi yang menggunakan sistem e-Registration memiliki persepsi yang sangat baik mengenai penerapan sistem e-Registration terlihat dari total rata-rata sebesar 4,22.

Indikator yang memiliki rata-rata terbesar mengenai sistem e-Registration dengan diterapkanya sistem e-Registration, wajib pajak dapat dengan mudah melakukan pendaftaran secara online memiliki skor rata-rata 4,33. Berdasarkan jawaban responden wajib pajak terlihat dari 5 indikator pernyataan terdapat 2 indikator yang mempunyai nilai rata-rata terkecil. Indikator ketiga yang mengenai sistem e-Registration dengan diterapkannya sistem e-Registration, wajib pajak dapat melakukan pendaftaran wajib pajak baru jika ingin memperoleh nomor NPWP memiliki rata-rata sebesar 4,14. Indikator keempat tentang dengan diterapkannya sistem e-Registration, wajib pajak tidak perlu lagi menunggu berkas pendaftaran dari wajib pajak untuk melakukan proses validasi NPWP.

\section{b. Pengaruh Penerapan Sistem e-SPT terhadap Kepatuhan Wajib Pajak}

Hasil penelitian menunjukkan bahwa sistem e-SPT tidak berpengaruh terhadap kepatuhan wajib pajak, sedangkan hasil uji signifikan simultan sistem e-SPT berpengaruh terhadap kepatuhan wajib pajak. Berdasarkan data yang diperoleh dari jawaban responden 
pada kuesioner secara keseluruhan wajib pajak orang pribadi yang menggunakan sistem eSPT memiliki persepsi yang sangat baik mengenai sistem e-SPT terlihat pada total rata-rata keseluruhan sebesar 4,21. Indikator yang memiliki rata-rata terbesar mengenai sistem eSPT dengan diterapkanya sistem e-SPT, wajib pajak dapat menyampaikan SPT secara cepat dan aman, karena lampiran dalam bentuk media CD/ flasdisk memiliki rata-rata 4,29.

Berdasarkan jawaban wajib pajak terlihat dari 5 indikator pernyataan terdapat 2 indikator yang mempunyai nilai rata-rata terkecil. Indikator pertama tentang sistem e-SPT mudah dipelajari oleh pengguna (user friendly)memiliki nilai rata-rata sebesar 4,07 dan indikator kedua tentang sistem e-SPT dapat merekam data dengan cepat memiliki nilai ratarata 4,18. Jawaban responden wajib pajak tentang kepatuhan wajib pajak dari 5 indikator pernyataan terdapat 1 indikator yang memiliki nilai rata- rata kecil. Indikator kelima tentang wajib pajak harus membayar kekurangan pajak yang ada sebelum dilakukan pemeriksaan memiliki rata-rata sebesar 4,17.

\section{c. Pengaruh Penerapan Sistem e-Filling terhadap Kepatuhan Wajib Pajak}

Hasil penelitian menunjukkan bahwa Penerapan Sistem e-Filling berpengaruh terhadap kepatuhan wajib pajak. Hal ini menunjukkan bahwa apabila sistem e-Filling semakin baik, maka kepatuhan wajib pajak akan semakin meningkat. Hal tersebut dipertegas melalui statistik dari jawaban responden tentang Sistem e-Filling pada Wajib Pajak diKPP Pratama Semarang Timur. Dilihat bahwa nilai rata-rata pada deskriptif statistik pada sistem e-Filling yaitu sebesar 4,32 yang berada dalam kategori tinggi. Diketahui nilai rata-rata sistem $e$ Filling sebesar 4,32, artinya dari 100 responden tanggapan responden terhadap indikator sistem e-Filling rata-rata responden menjawab pernyataan dengan jawaban sangat setuju dengan nilai yang diatas rata-rata sebanyak 51 responden. Hal ini menunjukkan bahwa Sistem e-Filling dapat mempengaruhi kepatuhan wajib pajak di KPP Pratama Semarang Timur.

Dalam objek yang diteliti, Sistem e-Filling untuk memudahkan wajib pajak dalam pelaporan SPT sudah dilaksanakan secara optimal. Penggunaan sistem perpajakan yang baik memberikan kemudahan bagi wajib pajak orang pribadi.Penerapan sistem e-Filling tidak terlepas dari berbagai perilaku pemikiran wajib pajak seperti keunggulan sistem, kemudahan sistem dan kondisi yang memfasilitasinya yang dapat memudahkan wajib pajak dalam pelaporan SPT. E-Filling merupakan sistem yang memfasilitasi pelaporan pajak menjadi lebih mudah dan cepat yang berdampak positif bagi wajib pajak sehingga menunjukkan sistem $e$ Filling berpengaruh terhadap kepatuhan wajib pajak.

\section{Kesimpulan}

Berdasarkan hasil penelitian dan pembahasan yang telah dijelaskan, maka diperoleh beberapa kesimpulan sebagai berikut:

a. Sistem e-Registration secara signifikan tidak berpengaruh terhadap kepatuhan wajib pajak, hal ini menunjukkan bahwa penggunaan sistem e-Registration tidak mempengaruhi kepatuhan wajib pajak di dalam memenuhi kewajiban perpajakannya.

b. Sistem e-SPT secara signifikan tidak berpengaruh terhadap kepatuhan wajib pajak, hal ini menunjukkan bahwa penggunaan sistem e-SPT tidak mempengaruhi kepatuhan wajib pajak di dalam memenuhi kewajiban perpajakannya.

c. Sistem e-Filling secara signifikan berpengaruh terhadap kepatuhan wajib pajak, hal ini menunjukkan bahwa dengan meningkatnya penggunaan sistem e-Filling dapat meningkatkan kepatuhan wajib pajak dalam memenuhi kewajiban perpajakannya.

\section{Daftar Pustaka}

Fenny syafariani, Ronauli Nadeak. 2015. "Peran Kualitas Sistem e-Registration terhadap Kepuasan Pengguna dan Kepatuhan Wajib Pajak di Kantor Pelayanan Pajak (KPP) Pratama Cimahi".

Firdaus, Topowijono, dan Devi. 2015. "Pengaruh Penerapan e-SPT dan Pengetahuan Perpajakan terhadap Kepatuhan Wajib Pajak". Jurnal Perpajakan. Vol.7 No.1 2015 pp. 1-7. Universitas Brawijaya

Ghozali, Imam dan Dwi Ratmono. 2013. Analisis Multivariat dan Ekonometrika teori, Konsep dan Aplikasi dengan eviews 8. Badn Penerbit Universitas Diponegoro Semarang. 
Hidayat, Widi Nugroho, Argo Adhi. 2010. Studi Empiris Theory of Planned Behavior dan Pengaruh Kewajiban Moral pada Perilaku Ketidakpatuhan Pajak Wajib Pajak Orang Pribadi. Jurnal Akuntansi dan Keuangan, Vol. 2 No. 2. Surabaya : Universitas Airlangga Surabaya.

Indriantoro, Nur dan Bambang Supomo. 2014. Metodologi Penelitian Bisnis. Fakultas Ekonomika dan Bisnis Universitas Gajah Mada. Yogyakarta.

Jogiyanto. 2008. Sistem Informasi Keperilakuan. Edisi Revisi. Yogyakarta : ANDI.

Keputusan Direktorat Jenderal Pajak Nomor 47/PJ/2008 tentang Tata Cara Penyampaian Surat Pemberitahuan dan Penyampaian Pemberitahuan Perpanjangan Surat Pemberitahuan secara Elektronik (e-Filling) melalui Perusahaan Penyedia Jasa Aplikasi (ASP).

Keputusan Direktur Jenderal Pajak Nomor 6/PJ/2009 Tentang Tata Cara Penyampaian Surat Pemberitahuan dalam bentuk Elektronik. 